\title{
Effects of Glutamine on the Mucosal Structure and Immune Cells in the Intestines of Broiler Chickens Challenged with Salmonella Enteritidis
}

\section{author(s)}

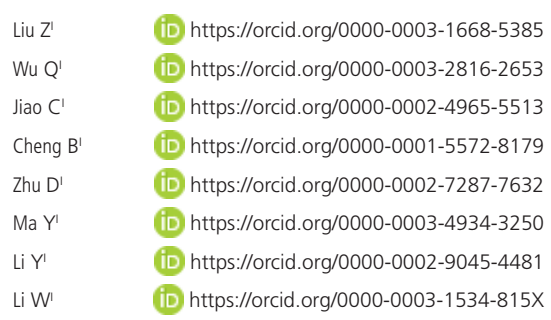

College of Animal Science and Technology, Henan University of Science and Technology, Luoyang 471003, Henan, PR China.

\section{-Mail Address}

Corresponding author e-mail address Wu Qiujue

College of Animal Science and Technology, Henan University of Science and

Technology, 263 Kaiyuan Avenue, Luoyang 471003, Henan, PR China.

Phone: +86 03796428234

Email: wuqiujue@163.com

\section{EKeywords}

Glutamine, intestinal villi, mucosal immunity, Salmonella Enteritidis, broiler.

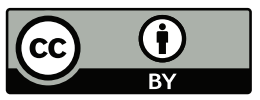

Submitted: 02/February/2020

Approved: 08/May/2020

\section{ABSTRACT}

The aim of this study was to investigate the effects of glutamine (GIn) on the intestinal mucosal structure and immune cells of broilers infected with Salmonella Enteritidis. 160 1-d-old commercial Arbor Acres (AA) broilers were randomly selected to receive one of four treatments, each of which had 5 replicates. Each replicate consisted of 8 chicks subjected to a 21-d feeding trial. Group I served as the unchallenged (CON). All birds in groups II (SCC) - IV were challenged with $2.0 \times 10^{4}$ $\mathrm{CFU} / \mathrm{mL}$ of $\mathrm{S}$. Enteritidis. The birds in groups III and IV were treated with $0.5 \%$ and $1.0 \% \mathrm{Gln}$. The results showed that S. Enteritidis infection led to a decrease in the relative length and weight, villus height:crypt depth $(\mathrm{VH}: \mathrm{CD})$ of the jejunum and ileum, the number of intraepithelial lymphocyte cells, and number of goblet cells and an increase in the number of mast goblet cells compared with the measurements of these parameters in the CON group $(p<0.05)$. In addition, the Gln groups had increased relative length and weight, $\mathrm{VH}: \mathrm{CD}$ of the jejunum and ileum, numbers of intraepithelial lymphocyte cells, and numbers of goblet cells and decreased crypt depth in the jejunum and ileum and numbers of mast goblet cells compared with the measurements of these parameters in the SCC group $(p<0.05)$. It was concluded that $\mathrm{Gln}$ added to broiler diets can effectively alleviate the intestinal mucosal damage caused by S. Enteritidis infection and improve its normal defense barrier function.

\section{INTRODUCTION}

Salmonella is a gram-negative bacteria widely found in nature and is a foodborne pathogen (Hohmann, 2001). Salmonella secretes invasion factor $\mathrm{E}$ in the small intestine, destroying host gastrointestinal epithelial cells by counteracting the sulfite released by immune cells and then compromising host defense mechanisms (Shanmugasundaram et al., 2015), leading to intestinal damage and decreased growth performance of broilers infected with Salmonella (Wang et al., 2012). Moreover, evidence from animal studies showed that Salmonella induces an increase in T regulatory cells (Tregs) in the small intestine of the infected broilers. IL-10 secreted by Tregs can suppress the host immune response, enabling Salmonella to survive in the small intestine (Paramasivam et al., 2019). Therefore, based on public demand for the rational use of antibiotics, new feed additives must be sought to alleviate the adverse effects of Salmonella infection.

Glutamine $(G \mid n)$ is the most important and most abundant amino acid in the human body. Among its functions, Gln has a role in protecting the intestinal mucosa, participating in the immune response, and in boosting protein synthesis (Bollhalder et al., 2013). Gln is a glucogenic amino acid that can be used as a precursor in the synthesis of nucleic acids, amino sugars and proteins (Souba, 1993). As a nonessential amino 
acid, GIn is an essential amino acid when the body is in a special state, such as during high-intensity exercise, during rapid environmental changes, and upon injury (Newsholme, 2001). Adding Gln to the diet prevented the intestinal and liver oxidative damage caused by intestinal ischemia and reperfusion in rats (Hartmann et al., 2017). Rats fed Gln in hypobaric or hypoxic conditions had regulated intestinal flora and reduced intestinal damage and adverse effects (Xu et al., 2014). Currently, the extent of the protective effect of GIn on the important mucosal structure and immune cells in broiler chickens infected with Salmonella remains unclear. Therefore, the aim of the present study was to evaluate the effects of glutamine on the mucosal structure and immune cells in the intestine of broiler chickens challenged with S. Enteritidis.

\section{MATERIALS AND METHODS}

\section{S. Enteritidis}

S. Enteritidis serotype was provided by the China Veterinary Culture Collection Center (CVCC 3377, Beijing, China). S. Enteritidis was cultured in Brilliant Green Agar at $37^{\circ} \mathrm{C}$ for $24 \mathrm{~h}$, washed, and then diluted to $2.0 \times 10^{4} \mathrm{CFU} / \mathrm{mL}$ in sterile normal saline. Colony counts by plating confirmed the viability of the cells.

\section{Glutamine}

The glutamine used in the experiment was purchased from Wuxi Jingyao Biotechnology Company Limited (Wuxi, Jiangsu, China) and had a purity of $99 \%$.

\section{Bird management and diets}

During the feeding study, the treatment of the birds complied with all of the specific regulations and requirements and was approved by the Institutional Animal Care and Use Committee of Henan University of Science and Technology.

One hundred and sixty 1-d-old commercial Arbor Acres (AA) broilers were obtained from a local commercial hatchery (Luoyang, Henan, China) and randomly allocated into four experimental groups for five replicate studies. The birds were weighed and placed in two separate 3-tier battery cages in an environmentally controlled room; the broilers were initially exposed to ambient temperature, which was gradually decreased from $34{ }^{\circ} \mathrm{C}$ to $22 \pm 1{ }^{\circ} \mathrm{C}$ until the birds reached $21 \mathrm{~d}$ of age. Plastic separators were used to prevent horizontal contamination between the cages. The experimental chickens were provided twenty-three $\mathrm{h}$ of light from days 1 to 7 and $18 \mathrm{~h}$ of light from days 8 to 21 .
The chickens were fed basic corn-soybean diets, the components of which are listed in Table 1. The diets were formulated based on the NRC (1994) to meet the nutrient requirements of the broilers.

Table 1 - Ingredients and nutrient level of the experimental diet ( $\mathrm{g} / \mathrm{kg}$ diet as fed basis).

\begin{tabular}{lc}
\hline Item & $1-21 \mathrm{~d}$ \\
\hline Feed Ingredients $(\mathrm{g} / \mathrm{kg})$ & 575 \\
\hline Corn silage & 327 \\
Soybean meal & 30 \\
Corn gluten meal & 28 \\
Soybean oil & 9.5 \\
\hline Limestone & 17.5 \\
Dicalcium phosphate & 3 \\
\hline Salt & 3.0 \\
Choline chloride & 3.0 \\
Premix & 2.5 \\
L-Lysine & 1.5 \\
DL-Methionine & 1,000 \\
\hline Total & \\
\hline Calculated nutrients levels (g/kg) & 14.5 \\
\hline AME (MJ/kg ) & 232.0 \\
CP & 10.7 \\
Ca & 4.2 \\
Available Phosphorus & 11.8 \\
Lys & 4.8 \\
Met & 9.1 \\
\hline Met+cys & \\
\hline
\end{tabular}

Note: ${ }^{1}$ Each $\mathrm{kg}$ of premix contained: Fe (from ferrous sulfate), $80 \mathrm{mg}$; $\mathrm{Cu}$ (from copper sulfate), 8 mg; Mn (from manganese sulfate), 110 mg; Zn (Bacitracin Zn), 65 mg; iodine (from calcium iodate), $1.1 \mathrm{mg}$; Se (from sodium selenite), $0.3 \mathrm{mg}$. Vitamin A (transretinyl acetate), 10,000 IU; Vitamin D3 (cholecalciferol), 3,000 IU; Vitamin E (all-rac- $\alpha$-tocopherolacetate), $30 \mathrm{IU}$; menadione, $1.3 \mathrm{mg}$; thiamine $2.2 \mathrm{mg}$; riboflavin, $8 \mathrm{mg}$; nicotinamide, $40 \mathrm{mg}$; calcium pantothenate, $10 \mathrm{mg}$; pyridoxine $\cdot \mathrm{HCl}, 4 \mathrm{mg}$; biotin, $0.04 \mathrm{mg}$; folic acid, $1 \mathrm{mg}$; vitamin B12 (cobalamine), $0.013 \mathrm{mg}$.

\section{Experimental protocol}

The broiler experiments were based on a completely randomized design with four treatment groups, each of which had five replicates. Each replicate consisted of 8 chicks which were subjected to a 21-d feeding trial. The 4 treatments were as follows: Group I was the control group (nonstress treated), and groups II (treated with S. Enteritidis), III (treated with S. Enteritidis and $0.5 \% \mathrm{GIn}$ ), and IV (treated with S. Enteritidis and $1.0 \% \mathrm{GIn}$ ) were the experimental groups. At the age of $3 \mathrm{~d}$, the broilers in experimental groups II, III and IV were administered $2.0 \times 10^{4} \mathrm{CFU} / \mathrm{mL}$ S. Enteritidis (0.5 $\mathrm{mL}$ ) orally, and the chicks of group I were treated with an equal volume of physiological saline.

\section{Sample collection and procedures}

At days 4, 7, 14 and 21, eight broilers (after being feed deprived for $12 \mathrm{~h}$ ) per cage were randomly selected and weighed. All birds were sacrificed by 
He L, Xu H, Ye F, Yu H, Lu Y, Yin H, Zhao X, Zhu Q, Wang Y
Effects of Glutamine on the Mucosal Structure and Immune Cells in the Intestines of Broiler Chickens Challenged with Salmonella Enteritidis exsanguination and dissected immediately. Then, the duodenum, jejunum and ileum were collected from each bird and flash frozen in liquid nitrogen and stored at $-80^{\circ} \mathrm{C}$.

\section{Relative length of the intestine}

The relative length of the intestine was calculated using the following formula: Relative length of the intestine $(\mathrm{cm} / \mathrm{kg})=$ Intestinal length $(\mathrm{cm}) /$ Live weight before slaughter $(\mathrm{kg})$.

\section{Relative weight of the intestine}

The relative weight of the intestine was calculated using the following formula: Relative weight of the intestine $(\mathrm{g} / \mathrm{kg})=$ Intestinal weight $(\mathrm{g}) /$ Live weight before slaughter $(\mathrm{kg})$.

\section{Small intestinal mucosal morphology}

The intestines were removed and washed repeatedly with physiological saline. For histological studies, about $2 \times 2 \mathrm{~cm}^{2}$ long samples from the proximal portion of the jejunum and ileum were collected and then placed in $4 \%$ formaldehyde prepared in advance. After $24 \mathrm{~h}$, the small intestine tissues were stained with hematoxylineosin (HE) to prepare the paraffin sections. The villus height, crypt depth and villus height/crypt depth were calculated.

\section{Observation and counting of the intestinal immune cells}

For each broiler, $2 \mathrm{~cm}$ middle duodenum, $1 \mathrm{~cm}$ jejunum segment near the yolk stalk and $1 \mathrm{~cm}$ ileum segment near the ileocecal orifice were sampled. Separate HE- and PAS-stained sections were observed under a Leica-DFC450 C microscope. Five well-stained sections selected from each intestine were observed under a light microscope at 40x and 10x magnification, photographed and counted. The sections with five longest fluff areas were selected from each photograph, and the number of intraepithelial lymphocytes, goblet cells and mast cells per 100 intestinal mucosal column cells was counted by the Image-Pro Plus 5.0 image analysis system.

\section{Statistical analysis}

All data were analyzed by one-way ANOVA with post hoc Duncan multiple comparison tests using SPSS statistical software (ver. 21.0 for Windows, SPSS Inc., Chicago, IL). The means and total standard errors are presented. Significance ( $P$ value) was evaluated at the 0.05 level.

\section{RESULTS}

\section{Relative length and relative weight of the small intestine}

In contrast to the control group, S. Enteritidis infection decreased the relative lengths of the duodenum (at 7 and 14 d), jejunum (at 4, 7 and $14 \mathrm{~d}$ ) and ileum (at 7, 14 and $21 \mathrm{~d}$ ) of the broilers $(p<0.05)$ (Table 2). However, the Gln 2 group showed increased relative lengths of the duodenum (at 7 and $14 \mathrm{~d}$ ), jejunum (at 4, 7 and $14 \mathrm{~d}$ ) and ileum (at 7, 14 and $21 \mathrm{~d}$ ) compared with those of the $S$. Enteritidis infection group $(p<0.05)$, although there were no differences when they were compared with the relative lengths of the duodenum, jejunum and ileum of the CON group ( $p>0.05)$, and the Gln 1 group showed increased relative length of the ileum (at 7, 14 and 21 d) compared with that of the $S$. Enteritidis infection group $(p<0.05)$, although there was no difference when it was compared with the relative length of the ileum of the CON group ( $p>0.05$ ).

Enteritidis infection decreased the relative weight of the duodenum (at $7 \mathrm{~d}$ ), jejunum (at $7 \mathrm{~d}$ ) and ileum (at 4, 7, 14 and $21 \mathrm{~d}$ ) of broilers $(p<0.05)$. The $\mathrm{G} \ln 2$ group had increased relative weights of the duodenum (at 7 d), jejunum (at 7 d) and ileum (at 4, 7, 14 and 21 d) compared with these weights of the $S$. Enteritidis infection group $(p<0.05)$, although there were no differences when they were compared with the relative weights of the duodenum (at $7 \mathrm{~d}$ ), jejunum (at $7 \mathrm{~d}$ ) and ileum (at 4, 7, 14 and $21 \mathrm{~d}$ ) of the CON group ( $p>0.05)$, and the Gln 1 group showed an increased relative weight of the ileum (at $4 \mathrm{~d}$ ) compared with that of the $S$. Enteritidis infection group $(p<0.05)$, although there was no difference when it was compared with the relative length of the ileum (at $4 \mathrm{~d}$ ) of the CON group ( $p>0.05)$. The secondary relationship between age and relative lengths of broiler small intestine is not obvious based on data regression analysis $\left(R^{2}<\right.$ 0.700 ). Based on the regression analysis of the data, a quadratic fitted curve between age and relative lengths of broiler small intestine is obtained y (duodenum, $0.5 \%$ Gln $)=-0.0095 x^{2}+0.6318 x+6.2015\left(R^{2}=\right.$ 0.8773 , the best effect is added at $14 \mathrm{~d}$ ); y (jejunum, $0.5 \% \mathrm{G} / \mathrm{n})=-0.0359 \mathrm{x}^{2}+1.6066 \mathrm{x}+14.975\left(\mathrm{R}^{2}=0.9322\right.$, the best effect is added at $7 \mathrm{~d}$ ); y (ileum, $0.5 \% \mathrm{Gln}$ ) $=-0.0413 x^{2}+1.648 x+5.0902\left(R^{2}=0.7906\right.$, the best effect is added at $7 \mathrm{~d}$ ); $y$ (duodenum, $1.0 \% \mathrm{Gln})=$ $-0.0362 x^{2}+1.1796 x+7.5453\left(R^{2}=0.651\right) ; y$ (jejunum, $1.0 \% \mathrm{G} \ln )=-0.0691 x^{2}+2.333 x+16.15\left(R^{2}=0.7805\right.$, the best effect is added at $7 \mathrm{~d}$ ); $y$ (ileum,1.0\% GIn) $=-0.079 x^{2}+2.7382 x+1.2632\left(R^{2}=0.9127\right.$, the best effect is added at $7 \mathrm{~d}$ ). 
Table 2 - Effect of dietary Gln on the relative length and relative weights of small intestine in broilers infected with S. Enteritidis.

\begin{tabular}{|c|c|c|c|c|c|}
\hline \multirow{2}{*}{ Items } & & \multicolumn{4}{|c|}{ Diet Treatments $^{1}$} \\
\hline & & $\mathrm{CON}$ & SCC & Gln1 & $\mathrm{G} \ln 2$ \\
\hline \multicolumn{6}{|c|}{ Relative length $(\mathrm{cm} / \mathrm{kg})$} \\
\hline \multirow{4}{*}{ Duodenum } & $4 d$ & $191.33 \pm 9.74$ & $176.25 \pm 12.06$ & $184.32 \pm 9.55$ & $194.67 \pm 11.39$ \\
\hline & $7 d$ & $204.10 \pm 2.77^{b}$ & $180.79 \pm 8.90^{a}$ & $196.09 \pm 3.92^{\mathrm{ab}}$ & $215.45 \pm 4.84^{b}$ \\
\hline & $14 d$ & $210.62 \pm 1.32^{b}$ & $189.67 \pm 0.64^{a}$ & $200.94 \pm 2.35^{\mathrm{ab}}$ & $220.38 \pm 4.78^{b}$ \\
\hline & $21 d$ & $223.79 \pm 4.25^{\mathrm{ab}}$ & $197.15 \pm 0.45^{a}$ & $213.88 \pm 1.65^{a}$ & $230.96 \pm 3.24^{b}$ \\
\hline \multirow{4}{*}{ Jejunum } & $4 d$ & $469.85 \pm 22.26^{b}$ & $440.12 \pm 1.15^{a}$ & $470.60 \pm 20.08^{a b}$ & $490.68 \pm 12.06^{b}$ \\
\hline & $7 d$ & $470.26 \pm 15.23^{b}$ & $449.41 \pm 11.15^{a}$ & $462.69 \pm 1.12^{\mathrm{a}}$ & $483.45 \pm 2.04^{b}$ \\
\hline & $14 d$ & $480.34 \pm 25.57^{b}$ & $454.27 \pm 20.95^{a}$ & $472.09 \pm 9.02^{\mathrm{ab}}$ & $512.15 \pm 2.38^{b}$ \\
\hline & $21 d$ & $502.47 \pm 51.85$ & $470.63 \pm 25.49$ & $490.21 \pm 8.51$ & $517.80 \pm 35.46$ \\
\hline \multirow{4}{*}{ lleum } & $4 d$ & $221.70 \pm 23.22$ & $207.07 \pm 32.22$ & $214.48 \pm 15.01$ & $238.35 \pm 16.43$ \\
\hline & $7 d$ & $236.08 \pm 10.89^{b}$ & $186.07 \pm 20.01^{a}$ & $233.75 \pm 16.38^{b}$ & $245.18 \pm 15.63^{b}$ \\
\hline & $14 d$ & $236.45 \pm 0.30^{b}$ & $221.03 \pm 0.33^{a}$ & $235.20 \pm 1.05^{b}$ & $261.28 \pm 0.07^{b}$ \\
\hline & $21 d$ & $250.45 \pm 0.44^{b}$ & $225.34 \pm 0.32^{\mathrm{a}}$ & $268.94 \pm 1.02^{b}$ & $268.25 \pm 0.08^{b}$ \\
\hline \multicolumn{6}{|c|}{ Relative weights $(\mathrm{g} / \mathrm{kg}$ ) } \\
\hline \multirow{5}{*}{ Duodenum } & $4 d$ & $9.10 \pm 0.51$ & $8.70 \pm 0.99$ & $8.87 \pm 1.35$ & $10.65 \pm 1.21$ \\
\hline & $7 d$ & $11.27 \pm 1.83^{b}$ & $9.11 \pm 1.30^{a}$ & $9.65 \pm 0.62^{\mathrm{ab}}$ & $15.82 \pm 2.02^{b}$ \\
\hline & $14 d$ & $13.56 \pm 0.56$ & $11.29 \pm 1.49$ & $13.49 \pm 1.22$ & $15.88 \pm 0.03$ \\
\hline & $21 d$ & $15.25 \pm 0.52$ & $13.14 \pm 0.09$ & $15.19 \pm 1.15$ & $16.65 \pm 0.07$ \\
\hline & $4 d$ & $21.16 \pm 2.95$ & $20.18 \pm 2.24$ & $20.44 \pm 2.12$ & $22.49 \pm 1.20$ \\
\hline \multirow{3}{*}{ Jejunum } & $7 d$ & $27.71 \pm 3.63^{b}$ & $21.59 \pm 1.14^{a}$ & $25.13 \pm 0.63^{\mathrm{ab}}$ & $32.37 \pm 1.79^{b}$ \\
\hline & $14 d$ & $31.43 \pm 1.10$ & $28.85 \pm 3.83$ & $30.02 \pm 1.07$ & $33.31 \pm 0.02$ \\
\hline & $21 d$ & $33.10 \pm 0.01$ & $30.25 \pm 2.21$ & $32.98 \pm 1.03$ & $35.26 \pm 0.01$ \\
\hline \multirow{4}{*}{ Ileum } & $4 d$ & $9.50 \pm 0.90^{b}$ & $7.06 \pm 1.03^{a}$ & $9.38 \pm 1.39^{b}$ & $9.51 \pm 0.87^{b}$ \\
\hline & $7 d$ & $17.89 \pm 0.98^{b}$ & $12.20 \pm 0.80^{a}$ & $17.45 \pm 2.18^{\mathrm{ab}}$ & $19.06 \pm 0.58^{b}$ \\
\hline & $14 d$ & $19.87 \pm 0.14^{b}$ & $16.07 \pm 3.25^{\mathrm{a}}$ & $18.36 \pm 0.60^{\mathrm{ab}}$ & $22.61 \pm 0.01^{b}$ \\
\hline & $21 d$ & $22.86 \pm 0.16^{b}$ & $18.98 \pm 2.10^{\mathrm{a}}$ & $21.99 \pm 0.12^{\mathrm{ab}}$ & $24.36 \pm 0.02^{\mathrm{b}}$ \\
\hline
\end{tabular}

${ }^{1} \mathrm{CON}=$ noninfect control group, $\mathrm{SCC}=$ S. Enteritidis infect control group received the basal diet, $\mathrm{Gln} 1=S$. Enteritidis infect control group received the basal diet plus $0.5 \% \mathrm{Gln} ; \mathrm{Gln} 2=$ S. Enteritidis infect control group received the basal diet plus $1.0 \% \mathrm{Gln}$.

$2, \mathrm{a}, \mathrm{b}$ Values within the same row that do not share a common superscript are significantly different at $p<0.05 ; \mathrm{n}=8$

\section{Morphology of the intestinal mucosa}

Our findings regarding the morphology of the intestinal mucosa are given in Table 3 . At days 4, 7, 14 , and 21 , in contrast to the control group, the $S$. Enteritidis infection broiler group showed significantly decreased villus height and $V H: C D$ in the jejunum (except at $d 21$ ) and ileum $(p<0.05)$. Compared with those of the $S$. Enteritidis challenged groups, the villus height and $V H: C D$ in the jejunum (except at $d 21$ ) and ileum in the Gln treatment groups were higher than they were in the $S$. Enteritidis infection group $(p<0.05)$, but there were no differences when they were compared with the villus height and $\mathrm{VH}: \mathrm{CD}$ in the jejunum (except at $d 21$ ) and ileum in the CON treatment group ( $p>0.05)$.

At days $4,7,14$, and 21 , the crypt depths in the jejunum (except at $d$ 21) and ileum were significantly increased in the $S$. Enteritidis infection group compared with those of the CON group $(p<0.05)$. However, the Gln 1 and $G \ln 2$ groups showed decreased crypt depths in the jejunum (except at $d 21)$ and ileum $(p<0.05)$ compared with the crypt depths in the jejunum and ileum of the $S$. Enteritidis infection group, although there were no significant differences when they were compared with the crypt depths in the jejunum (except $d 21$ ) and ileum of the CON group ( $p>0.05$ ). The secondary relationship between age and $\mathrm{VH}: \mathrm{CD}$ of broiler small intestine is not obvious based on data regression analysis $\left(R^{2}<0.700\right)$.

\section{Number of intraepithelial lymphocytes}

The number of intraperitoneal lymphocyte cells in the duodenum, jejunum and ileum was significantly decreased in the $S$. Enteritidis infection group compared with that of the CON group at 4, 7, 14 and $21 \mathrm{~d}$ of age $(p<0.05)$ (Table 4$)$. Compared with the $S$. Enteritidis challenged groups, the number of intraperitoneal lymphocyte cells in the duodenum, jejunum and ileum in the Gln treatment was higher than that in the $S$. Enteritidis infection group $(p<0.05)$, and there was no difference when it was compared with the number of intraperitoneal lymphocyte cells in 
Table 3 - Effect of dietary GIn on the morphology $(\mu \mathrm{m})$ of the intestinal mucosa in broilers infected with $\mathrm{S}$. Enteritidis.

\begin{tabular}{|c|c|c|c|c|c|}
\hline \multirow{2}{*}{ Items } & & \multicolumn{4}{|c|}{ Diet Treatments $^{1}$} \\
\hline & & CON & SCC & Gln1 & $\mathrm{G} \ln 2$ \\
\hline \multicolumn{6}{|l|}{$4 d$} \\
\hline \multirow{3}{*}{ Jejunum } & Villus height & $651.65 \pm 30.10^{b}$ & $556.31 \pm 16.71^{\mathrm{a}}$ & $643.01 \pm 20.31^{b}$ & $648.13 \pm 24.07^{b}$ \\
\hline & Crypt depth & $90.12 \pm 8.37^{a}$ & $112.06 \pm 9.18^{b}$ & $96.68 \pm 7.64^{a}$ & $95.01 \pm 8.35^{a}$ \\
\hline & Villus height:crypt depth & $7.23 \pm 1.02^{b}$ & $4.96 \pm 0.95^{\mathrm{a}}$ & $6.65 \pm 1.10^{b}$ & $6.82 \pm 0.87^{b}$ \\
\hline \multirow{3}{*}{ lleum } & Villus height & $418.37 \pm 20.38^{b}$ & $386.29 \pm 16.47^{a}$ & $405.34 \pm 16.31^{b}$ & $410.13 \pm 19.16^{b}$ \\
\hline & Crypt depth & $108.04 \pm 8.01^{a}$ & $123.68 \pm 10.14^{b}$ & $112.19 \pm 8.31^{\mathrm{a}}$ & $110.92 \pm 7.52^{a}$ \\
\hline & Villus height:crypt depth & $3.87 \pm 0.27^{b}$ & $3.12 \pm 0.16^{a}$ & $3.61 \pm 0.19^{b}$ & $3.70 \pm 0.11^{\mathrm{b}}$ \\
\hline \multicolumn{6}{|c|}{$7 \mathrm{~d}$} \\
\hline \multirow{3}{*}{ Jejunum } & Villus height & $756.12 \pm 30.15^{b}$ & $612.03 \pm 21.20^{a}$ & $728.92 \pm 17.91^{b}$ & $744.91 \pm 22.83^{b}$ \\
\hline & Crypt depth & $96.54 \pm 10.03^{a}$ & $117.04 \pm 8.81^{b}$ & $98.37 \pm 8.67^{a}$ & $95.94 \pm 9.20^{\mathrm{a}}$ \\
\hline & Villus height:crypt depth & $7.83 \pm 0.86^{b}$ & $5.23 \pm 0.69^{a}$ & $7.41 \pm 0.81^{b}$ & $7.76 \pm 0.93^{b}$ \\
\hline \multirow{3}{*}{ lleum } & Villus height & $452.64 \pm 18.67^{b}$ & $401.75 \pm 10.75^{a}$ & $442.18 \pm 12.06^{b}$ & $448.61 \pm 11.14^{b}$ \\
\hline & Crypt depth & $118.34 \pm 7.38^{a}$ & $138.48 \pm 9.01^{b}$ & $119.26 \pm 9.27^{a}$ & $117.13 \pm 8.64^{a}$ \\
\hline & Villus height:crypt depth & $3.83 \pm 0.86^{b}$ & $2.91 \pm 0.75^{\mathrm{a}}$ & $3.71 \pm 0.63^{b}$ & $3.83 \pm 0.81^{\mathrm{b}}$ \\
\hline \multicolumn{6}{|l|}{$14 \mathrm{~d}$} \\
\hline \multirow{3}{*}{ Jejunum } & Villus height & $1004.59 \pm 25.34^{b}$ & $869.23 \pm 34.18^{a}$ & $990.37 \pm 19.43^{b}$ & $999.17 \pm 30.75^{b}$ \\
\hline & Crypt depth & $122.81 \pm 7.45^{\mathrm{a}}$ & $130.17 \pm 6.21^{b}$ & $125.07 \pm 5.98^{\mathrm{a}}$ & $123.75 \pm 4.25^{\mathrm{a}}$ \\
\hline & Villus height:crypt depth & $8.18 \pm 0.59^{b}$ & $6.68 \pm 0.76^{a}$ & $7.92 \pm 0.63^{b}$ & $8.07 \pm 0.49^{b}$ \\
\hline \multirow{3}{*}{ Ileum } & Villus height & $572.14 \pm 25.01^{b}$ & $477.05 \pm 18.43^{a}$ & $549.18 \pm 15.27^{b}$ & $557.83 \pm 10.46^{b}$ \\
\hline & Crypt depth & $130.28 \pm 12.01^{a}$ & $152.92 \pm 7.63^{b}$ & $136.34 \pm 10.04^{a}$ & $133.71 \pm 8.25^{a}$ \\
\hline & Villus height:crypt depth & $4.39 \pm 0.58^{b}$ & $3.12 \pm 0.67^{a}$ & $4.03 \pm 0.81^{b}$ & $4.17 \pm 0.75^{b}$ \\
\hline \multicolumn{6}{|l|}{$21 \mathrm{~d}$} \\
\hline \multirow{3}{*}{ Jejunum } & Villus height & $1135.31 \pm 65.07$ & $1100.37 \pm 42.51$ & $1112.65 \pm 54.64$ & $1127.38 \pm 70.13$ \\
\hline & Crypt depth & $134.36 \pm 16.87$ & $138.36 \pm 18.67$ & $136.09 \pm 10.02$ & $134.32 \pm 9.64$ \\
\hline & Villus height:crypt depth & $8.45 \pm 1.02$ & $7.95 \pm 2.25$ & $8.18 \pm 2.99$ & $8.39 \pm 1.11$ \\
\hline \multirow{3}{*}{ Ileum } & Villus height & $744.12 \pm 16.37^{b}$ & $607.25 \pm 13.84^{a}$ & $721.08 \pm 19.62^{b}$ & $738.94 \pm 16.34^{b}$ \\
\hline & Crypt depth & $136.12 \pm 9.31^{\mathrm{a}}$ & $154.27 \pm 7.69^{b}$ & $140.02 \pm 8.63^{a}$ & $138.18 \pm 10.02^{a}$ \\
\hline & Villus height:crypt depth & $5.47 \pm 0.25^{b}$ & $3.94 \pm 0.39^{a}$ & $5.15 \pm 0.46^{b}$ & $5.35 \pm 0.27^{b}$ \\
\hline
\end{tabular}

${ }^{1} \mathrm{CON}=$ noninfect control group, $\mathrm{SCC}=S$. Enteritidis infect control group received the basal diet, $\mathrm{Gln} 1=S$. Enteritidis infect control group received the basal diet plus $0.5 \% \mathrm{Gln} ; \mathrm{Gln} 2=$ S. Enteritidis infect control group received the basal diet plus $1.0 \% \mathrm{Gln}$.

$2, \mathrm{a}, \mathrm{b}$ Values within the same row that do not share a common superscript are significantly different at $p<0.05 ; \mathrm{n}=8$.

the duodenum, jejunum and ileum in the CON group $(p>0.05)$. Based on the regression analysis of the data, a quadratic fitted curve is obtained y (duodenum, $0.5 \%$ GIn $)=-0.0334 x^{2}+1.3319 x+6.9874 \quad\left(R^{2}=\right.$ 0.9156 , the best effect is added at $7 \mathrm{~d}$ ); y (jejunum, $0.5 \%$ Gln $)=-0.0205 x^{2}+0.9898 x+7.5121\left(R^{2}=0.892\right.$, the best effect is added at $7 \mathrm{~d}$ ); $y$ (ileum, $0.5 \% \mathrm{Gln}$ ) $=-0.0169 x^{2}+0.8621 x+6.2603 \quad\left(R^{2}=0.9202\right.$, the best effect is added at $7 \mathrm{~d}$ ); y (duodenum, $1.0 \%$ $G \mid n)=-0.0199 x^{2}+0.9827 x+9.2279 \quad\left(R^{2}=0.9032\right.$, the best effect is added at $14 \mathrm{~d}$ ); y (jejunum, $1.0 \%$ $\mathrm{G} \ln )=-0.0186 \mathrm{x}^{2}+0.9601 \mathrm{x}+7.8006 \quad\left(\mathrm{R}^{2}=0.9155\right.$, the best effect is added at $7 \mathrm{~d}$ ); $y$ (ileum, $1.0 \% \mathrm{Gln}$ ) $=-0.0199 x^{2}+0.9208 x+6.4477\left(R^{2}=0.9289\right.$, the best effect is added at $7 \mathrm{~d}$ ).

\section{Number of intestinal goblet cells}

At days 4, 7, 14 and 21, the number of intestinal goblet cells in the duodenum (except at $d$ 21), jejunum (except at d 21) and ileum (except at $d 4$ ) was significantly decreased in the $S$. Enteritidis infection group compared with that of the CON group $(p<0.05)$ (Table 5). However, Salmonella-challenged broilers treated with Gln supplements (groups Gln 1 and Gln 2) had an increased number of intestine goblet cells in the duodenum (except at d 21), jejunum (except at $d$ 21) and ileum (except at d 4) compared with that of the $S$. Enteritidis infection group $(p<0.05)$, although there was no difference when it was compared with the number of intestinal goblet cells in the duodenum, jejunum and ileum of the CON group ( $p>0.05)$. Based on the regression analysis of the data, a quadratic fitted curve is obtained $y$ (duodenum, 0.5\% Gln) $=-0.0085 x^{2}+0.6466 x+6.8477$ $\left(R^{2}=0.9336\right.$, the best effect is added at $\left.7 d\right) ; y$ (jejunum, $0.5 \%$ GIn) $=-0.0015 x^{2}+0.4553 x+9.3286$ $\left(R^{2}=0.8641\right.$, the best effect is added at $\left.7 \mathrm{~d}\right) ; \mathrm{y}$ (ileum, $0.5 \% G \ln )=0.0094 x^{2}+0.0757 x+12.837\left(R^{2}=0.9028\right.$, the best effect is added at $7 \mathrm{~d}$ ); $y$ (duodenum, $1.0 \%$ $G(n)=0.0128 x^{2}+0.7704 x+6.6386\left(R^{2}=0.9117\right.$, the 
Table 4 - Effect of dietary GIn on the number of the intraepithelial lymphocyte cells in broilers infected with $S$. Enteritidis (Entries/100 absorptive cells).

\begin{tabular}{|c|c|c|c|c|}
\hline \multirow{2}{*}{ Items } & \multicolumn{4}{|c|}{ Diet Treatments ${ }^{1}$} \\
\hline & CON & SCC & $\mathrm{G} \ln 1$ & $\mathrm{G} \ln 2$ \\
\hline \multicolumn{5}{|l|}{$4 d$} \\
\hline Duodenum & $12.04 \pm 0.28^{b}$ & $8.38 \pm 0.51^{a}$ & $11.61 \pm 1.04^{b}$ & $11.93 \pm 0.95^{b}$ \\
\hline Jejunum & $11.20 \pm 1.24^{b}$ & $7.92 \pm 0.28^{\mathrm{a}}$ & $10.88 \pm 0.81^{b}$ & $11.08 \pm 1.57^{b}$ \\
\hline Ileum & $9.73 \pm 0.27^{b}$ & $6.67 \pm 0.62^{a}$ & $9.24 \pm 0.40^{b}$ & $9.65 \pm 0.52^{b}$ \\
\hline \multicolumn{5}{|l|}{$7 d$} \\
\hline Duodenum & $15.84 \pm 0.31^{b}$ & $10.23 \pm 0.52^{a}$ & $14.97 \pm 0.86^{b}$ & $15.06 \pm 0.71^{b}$ \\
\hline Jejunum & $14.67 \pm 0.27^{b}$ & $9.37 \pm 0.61^{a}$ & $13.89 \pm 0.81^{b}$ & $14.07 \pm 0.53^{b}$ \\
\hline Ileum & $12.37 \pm 0.28^{b}$ & $8.69 \pm 0.55^{a}$ & $11.81 \pm 0.34^{b}$ & $12.20 \pm 0.61^{b}$ \\
\hline \multicolumn{5}{|l|}{$14 \mathrm{~d}$} \\
\hline Duodenum & $19.20 \pm 0.13^{b}$ & $11.42 \pm 0.63^{a}$ & $18.91 \pm 0.79^{b}$ & $19.12 \pm 0.88^{b}$ \\
\hline Jejunum & $17.26 \pm 0.29^{b}$ & $10.63 \pm 0.45^{a}$ & $17.07 \pm 0.67^{b}$ & $17.33 \pm 0.27^{b}$ \\
\hline Ileum & $15.32 \pm 0.31^{b}$ & $9.67 \pm 0.30^{a}$ & $14.81 \pm 0.27^{b}$ & $15.27 \pm 0.35^{b}$ \\
\hline \multicolumn{5}{|l|}{$21 \mathrm{~d}$} \\
\hline Duodenum & $21.56 \pm 1.83^{b}$ & $13.67 \pm 2.15^{\mathrm{a}}$ & $20.28 \pm 1.78^{b}$ & $21.06 \pm 1.89^{b}$ \\
\hline Jejunum & $20.17 \pm 1.41^{b}$ & $11.67 \pm 2.18^{a}$ & $19.32 \pm 2.23^{b}$ & $19.86 \pm 1.63^{b}$ \\
\hline Ileum & $17.25 \pm 1.38^{b}$ & $10.08 \pm 2.10^{\mathrm{a}}$ & $16.97 \pm 1.85^{b}$ & $17.06 \pm 1.94^{b}$ \\
\hline
\end{tabular}

${ }^{1} \mathrm{CON}=$ noninfect control group, $\mathrm{SCC}=S$. Enteritidis infect control group received the basal diet, $\mathrm{Gln} 1=S$. Enteritidis infect control group received the basal diet plus $0.5 \% \mathrm{Gln} ; \mathrm{Gln} 2=$ S. Enteritidis infect control group received the basal diet plus $1.0 \% \mathrm{Gln}$.

$2, \mathrm{a}, \mathrm{b}$ Values within the same row that do not share a common superscript are significantly different at $p<0.05 ; \mathrm{n}=8$.

Table 5 - Effect of dietary Gln on the number of the intestine's goblet cells in broilers infected with S. Enteritidis (Entries/100 absorptive cells)

\begin{tabular}{|c|c|c|c|c|}
\hline \multirow{2}{*}{ Items } & \multicolumn{4}{|c|}{ Diet Treatments $^{1}$} \\
\hline & $\mathrm{CON}$ & $\overline{S C C}$ & $\mathrm{G} \ln 1$ & $\mathrm{G} \ln 2$ \\
\hline \multicolumn{5}{|l|}{$4 \mathrm{~d}$} \\
\hline Duodenum & $9.28 \pm 0.23^{b}$ & $6.53 \pm 0.17^{a}$ & $8.95 \pm 0.14^{b}$ & $9.19 \pm 0.22^{b}$ \\
\hline Jejunum & $11.13 \pm 0.18^{b}$ & $8.30 \pm 0.30^{a}$ & $10.65 \pm 0.21^{b}$ & $10.08 \pm 0.27^{b}$ \\
\hline Ileum & $13.59 \pm 0.20$ & $9.65 \pm 0.24$ & $13.07 \pm 0.18$ & $13.46 \pm 0.20$ \\
\hline \multicolumn{5}{|l|}{$7 d$} \\
\hline Duodenum & $12.10 \pm 0.15^{b}$ & $8.10 \pm 0.20^{a}$ & $11.56 \pm 0.27^{b}$ & $11.97 \pm 0.11^{b}$ \\
\hline Jejunum & $14.01 \pm 0.32^{b}$ & $10.27 \pm 0.40^{a}$ & $13.27 \pm 0.30^{\mathrm{b}}$ & $13.98 \pm 0.28^{b}$ \\
\hline lleum & $15.36 \pm 0.24^{b}$ & $12.11 \pm 0.14^{\mathrm{a}}$ & $14.21 \pm 0.19^{b}$ & $15.18 \pm 0.25^{b}$ \\
\hline \multicolumn{5}{|l|}{$14 \mathrm{~d}$} \\
\hline Duodenum & $14.73 \pm 0.12^{b}$ & $11.48 \pm 0.30^{\mathrm{a}}$ & $13.87 \pm 0.14^{b}$ & $14.58 \pm 0.16^{b}$ \\
\hline Jejunum & $15.39 \pm 0.62^{b}$ & $12.67 \pm 0.60^{a}$ & $14.92 \pm 0.17^{b}$ & $15.27 \pm 0.22^{b}$ \\
\hline Ileum & $16.21 \pm 0.42^{b}$ & $13.01 \pm 0.23^{a}$ & $15.51 \pm 0.37^{b}$ & $16.12 \pm 0.18^{b}$ \\
\hline \multicolumn{5}{|l|}{$21 \mathrm{~d}$} \\
\hline Duodenum & $17.89 \pm 1.05$ & $15.34 \pm 2.96$ & $16.96 \pm 1.37$ & $17.28 \pm 1.54$ \\
\hline Jejunum & $19.76 \pm 0.91$ & $17.92 \pm 1.87$ & $18.39 \pm 1.64$ & $19.27 \pm 1.89$ \\
\hline Ileum & $20.49 \pm 1.06^{b}$ & $14.31 \pm 0.84^{\mathrm{a}}$ & $18.64 \pm 0.92^{b}$ & $19.87 \pm 0.87^{b}$ \\
\hline
\end{tabular}

${ }^{1} \mathrm{CON}=$ noninfect control group, $\mathrm{SCC}=\mathrm{S}$. Enteritidis infect control group received the basal diet, Gln $1=S$. Enteritidis infect control group received the basal diet plus $0.5 \% \mathrm{Gln} ; \mathrm{Gln} 2=$ S. Enteritidis infect control group received the basal diet plus $1.0 \% \mathrm{Gln}$.

$2, a, b$ Values within the same row that do not share a common superscript are significantly different at $p<0.05 ; \mathrm{n}=8$.

best effect is added at $7 \mathrm{~d}$ ); $y$ (jejunum, $1.0 \% \mathrm{Gln}$ ) $=-0.0062 x^{2}+0.6343 x+8.4476 \quad\left(R^{2}=0.8577\right.$, the best effect is added at $7 \mathrm{~d}$ ); $y$ (ileum, $1.0 \% \mathrm{Gln}$ ) = $0.011 x^{2}+0.0695 x+13.426\left(R^{2}=0.9011\right.$, the best effect is added at $7 \mathrm{~d}$ ).

\section{Number of mast cells}

At days $4,7,14$ and 21 , the number of intestinal goblet cells in the duodenum (except at d 21), jejunum and ileum significantly increased in the $S$. Enteritidis infection group compared with that of the CON group $(p<0.05)$ (Table 6). The Gln 1 and Gln 2 groups each showed a significantly decreased number of intestinal goblet cells in the duodenum (except at d 21), jejunum and ileum compared with that of the $S$. Enteritidis infection group $(p<0.05)$. However, there were no differences in the number of intestinal goblet cells in the duodenum, jejunum and ileum of the Gln 1 
Table 6 - Effect of dietary GIn on the number of the mast cells in broilers infected with S. Enteritidis (Entries/100 absorptive cells).

\begin{tabular}{|c|c|c|c|c|}
\hline \multirow{2}{*}{ Items } & \multicolumn{4}{|c|}{ Diet Treatments $^{1}$} \\
\hline & $\mathrm{CON}$ & SCC & $\mathrm{G} \ln 1$ & $\mathrm{Gln} 2$ \\
\hline \multicolumn{5}{|l|}{$4 d$} \\
\hline Duodenum & $42.18 \pm 1.19^{a}$ & $51.43 \pm 1.82^{b}$ & $43.37 \pm 2.08^{a}$ & $42.85 \pm 1.64^{a}$ \\
\hline Jejunum & $30.92 \pm 1.50^{a}$ & $39.07 \pm 1.21^{b}$ & $32.01 \pm 2.17^{a}$ & $31.24 \pm 1.54^{a}$ \\
\hline Ileum & $29.42 \pm 1.01^{\mathrm{a}}$ & $37.35 \pm 1.14^{b}$ & $30.64 \pm 2.07^{a}$ & $30.20 \pm 1.30^{a}$ \\
\hline \multicolumn{5}{|l|}{$7 \mathrm{~d}$} \\
\hline Duodenum & $49.10 \pm 2.60^{a}$ & $60.01 \pm 1.08^{b}$ & $50.31 \pm 2.01^{\mathrm{a}}$ & $49.68 \pm 2.71^{\mathrm{a}}$ \\
\hline Jejunum & $33.61 \pm 1.30^{\mathrm{a}}$ & $44.83 \pm 1.11^{b}$ & $34.08 \pm 2.01^{\mathrm{a}}$ & $33.91 \pm 2.22^{\mathrm{a}}$ \\
\hline Ileum & $32.15 \pm 2.17^{\mathrm{a}}$ & $41.28 \pm 1.62^{b}$ & $33.63 \pm 3.11^{\mathrm{a}}$ & $32.79 \pm 1.09^{\mathrm{a}}$ \\
\hline \multicolumn{5}{|l|}{$14 \mathrm{~d}$} \\
\hline Duodenum & $57.36 \pm 3.64^{a}$ & $68.31 \pm 5.30^{b}$ & $58.52 \pm 4.37^{a}$ & $57.21 \pm 3.42^{\mathrm{a}}$ \\
\hline Jejunum & $38.07 \pm 1.69^{a}$ & $47.17 \pm 1.92^{b}$ & $39.48 \pm 1.91^{a}$ & $38.91 \pm 1.34^{a}$ \\
\hline Ileum & $37.46 \pm 1.39^{a}$ & $42.05 \pm 2.01^{b}$ & $38.69 \pm 1.83^{a}$ & $38.19 \pm 2.04^{a}$ \\
\hline \multicolumn{5}{|l|}{$21 \mathrm{~d}$} \\
\hline Duodenum & $68.25 \pm 5.17$ & $77.34 \pm 2.30$ & $69.07 \pm 2.19$ & $68.33 \pm 3.01$ \\
\hline Jejunum & $42.18 \pm 1.37^{a}$ & $51.05 \pm 1.38^{b}$ & $43.16 \pm 2.54^{a}$ & $42.49 \pm 1.17^{a}$ \\
\hline Ileum & $41.07 \pm 1.47^{\mathrm{a}}$ & $50.56 \pm 2.38^{b}$ & $42.06 \pm 2.01^{\mathrm{a}}$ & $41.38 \pm 2.37^{a}$ \\
\hline
\end{tabular}

${ }^{1} \mathrm{CON}=$ noninfect control group, $\mathrm{SCC}=\mathrm{S}$. Enteritidis infect control group received the basal diet, $\mathrm{Gln} 1=S$. Enteritidis infect control group received the basal diet plus $0.5 \% \mathrm{Gln} ; \mathrm{Gln} 2=$

S. Enteritidis infect control group received the basal diet plus $1.0 \% \mathrm{Gln}$.

$2, \mathrm{a}$, bValues within the same row that do not share a common superscript are significantly different at $p<0.05 ; \mathrm{n}=8$.

group, Gln 2 group, and CON group ( $p>0.05)$. Based on the regression analysis of the data, a quadratic fitted curve is obtained y (duodenum, $0.5 \% \mathrm{Gln}$ ) = $-0.0097 x^{2}+1.6926 x+37.552\left(R^{2}=0.9801\right.$, the best effect is added at $7 \mathrm{~d}$ ); y (jejunum, $0.5 \% \mathrm{GIn}$ ) = $0.0014 x^{2}+0.7209 x+29.052\left(R^{2}=0.943\right.$, the best effect is added at $14 \mathrm{~d}$ ); $y$ (ileum, $0.5 \% \mathrm{Gln}$ ) $=-0.0197 \mathrm{x}^{2}+1.16 \mathrm{x}$ $+26.374\left(R^{2}=0.8541\right.$, the best effect is added at $\left.14 \mathrm{~d}\right) ; \mathrm{y}$ (duodenum, 1.0\% GIn) $=-0.0015 x^{2}+1.4668 x+37.914$ $\left(R^{2}=0.9791\right.$, the best effect is added at $\left.7 \mathrm{~d}\right) ; \mathrm{y}$ (jejunum, $1.0 \% G \ln )=-0.0152 x^{2}+1.0414 x+27.336\left(R^{2}=0.9771\right.$, the best effect is added at $14 \mathrm{~d}$ ); $y$ (ileum, $1.0 \% \mathrm{Gln}$ ) $=-0.0193 x^{2}+1.1461 x+25.847\left(R^{2}=0.9011\right.$, the best effect is added at $14 \mathrm{~d}$ ).

\section{DISCUSSION}

The duodenum, jejunum, and ileum are important digestive and absorbing organs that play a vital role. Previous studies have shown that broiler stress can significantly reduce the relative weight and relative length of each intestinal tract, affecting intestinal development (Al-Fataftah et al., 2014; Garriga et al., 2006; Wu et al., 2019). In our experiment, results were obtained to support these previous findings, and the relative length and relative weight of the small intestine were reduced in the broilers infected with $S$. Enteritidis. This outcome may be related to the fact that Salmonella can cause intestinal inflammation and increase proinflammatory cytokines, which in turn can increase intestinal damage and nutrient loss (Wang et al., 2019; Dinarello, 2000). However, the results from the dietary GIn supplementation experiments showed that the abovementioned clinical symptoms disappeared; the relative length and relative weight of each intestinal segment of the small intestine increased compared with those of the SCC group after 1.0\% Gln was added to the diet given to the broilers infected with Salmonella, and when 0.5\% Gln was added, the effect of the infection was weak. This finding may indicate that the addition of GIn to the broiler diets improved the intestinal physiology and promoted the recovery of the damaged intestinal tract (Bortoluzzi et al., 2017). This outcome may be due to glutamine serving as a major source of energy for proliferating intestinal cells (Akiba et al., 2009).

The small intestine is an important place where the body absorbs nutrients. The intestinal mucosa plays an important role in the digestion and absorption of nutrients. The increase in villus height is beneficial for the absorption of nutrients, but the increase in crypt depth is not conducive. It is generally believed that the absorption of nutrients increases as the ratio of $\mathrm{VH}: \mathrm{CD}$ increases (Awad et al., 2009). In our present study, S. Enteritidis infection led to a significant decrease in villus height and a significant increase in crypt depth such that the VH:CD was reduced in the broilers infected with Salmonella. Similarly, previous reports showed that the $\mathrm{VH}: \mathrm{CD}$ in the small intestine significantly reduced upon Salmonella infection (Andrade et al., 2013; Shao 
et al., 2014; Jazi et al., 2018; Wu et al., 2020). This outcome may be the result of Salmonella damaging the intestinal mucosa, affecting the absorption of nutrients, weakening the body's resistance, and then aggravating the intestinal mucosa. Our present experimental results indicated that, after feeding broilers with Gln supplemented diets, the villus height increased, the crypt depth decreased, and the $\mathrm{VH}: \mathrm{CD}$ increased compared to these parameters in the SCC group. Similar findings were reported for broilers fed Gln (Bartell et al., 2007; Wu et al., 2018; Barekatain et al., 2019), mice fed Gln (Huang et al., 2005; Sukhotnik et al., 2007), and piglets fed GIn (Wu et al., 1996; Wang et al., 2008). According to the findings described above, it can be concluded that adding GIn to feed can help protect the intestinal mucosa. This result may be related to the addition of Gln to the diet increasing the expression of genes that prevent oxidative activity (Wu et al., 2019).

There are a large number of intraepithelial lymphocytes with strong immune function in the intestinal mucosa, and these lymphocytes play an important role in resisting infection through immunity and maintaining the integrity of the intestine (Shi et al., 2015). Previous studies have shown that the number of intraepithelial lymphocytes gradually decreases in stressed broilers (Shi et al., 2015). Our study obtained similar results: under physiological conditions, the number of intestinal intraepithelial lymphocytes in the broilers significantly reduced upon Salmonella infection. This finding may be related to the ability of Salmonella to invade cells and induce the intracellular expression of inflammatory cytokines to cause inflammation, thus destroying the intestinal mucosa (Galan, 1998). Our study indicates that the number of intestinal intraepithelial lymphocytes significantly increased in the broilers fed a diet with $0.5 \%$ or $1.0 \%$ Gln. Similarly, Swaid's study (Swaid et al., 2013) showed that the addition of Gln to the diet prevented mucosal damage and improved intestinal recovery after intestinal injury in rats, and in Kew S's study (Kew et al., 1999), the addition of GIn to mouse diets enhanced $\mathrm{T}$ lymphocyte proliferation. These results were likely attributable to the ability of Gln to reduce the level of the inflammatory factor TNF- $\alpha$ and to decrease the apoptosis of intestinal epithelial cells (Wu et al., 2019). It may also be related to the ability of GIn to provide energy for intestinal epithelial lymphocytes and promote the repair of the damaged intestinal tracts (Schoor et al., 2010).

Intestinal goblet cells play an important role in intestinal immunity; they can secrete mucin and some bioactive molecules, forming an outer layer of cells that prevents the invasion of bacteria and protects the body from damage (Kim et al., 2010). In this study, broilers infected with S. Enteritidis had a reduced number of intestine goblet cells compared with those in the uninfected broilers, a finding that was similar to that of a previous study (Zhen et al., 2018). These findings may be related to the colonization of the intestinal tract by Salmonella and the downregulation of jejunal mucin, which in turn causes intestinal inflammation and impaired barrier function. This finding indicates that S. Enteritidis infection endangers intestinal health in broilers. However, broilers receiving GIn-supplemented diets showed increased goblet cell numbers in the small intestine, indicating that supplementing Gln had a positive role in controlling $S$. Enteritidis infection. Similar to our results, those of another study in which Gln was added to the diet of weaned piglets resulted in a significantly increased number of goblet cells in the duodenum and ileum epithelium (Xing et al., 2017), which may have been related to the ability of GIn to enhance the proliferation of the intestinal stem cells and the promotion of their differentiation into goblet cells (Chen et al., 2019). In contrast, it has been reported that adding GIn to the diets of weaned mice had no effect on the number of intestinal goblet cells (Chen et al., 2018), but another study showed that feeding GIn in tumor-bearing rats reduced the number of goblet cells in the duodenum and jejunum (Martins et al., 2016). This finding is different from that of our experiments and may be related to different species and infection patterns.

Broiler small intestine mast cells are important immune-active cells that can attract granulocytes and lymphocytes to the site of stimulation through paracrine cytokines, regulate intestinal homeostasis, and participate in the immune process after infection in the body (Bischoff et al., 2009). Öhman and VivinusNébot studies (Öhman et al., 2010; Vivinus et al., 2012) have shown that mast cells are associated with irritable bowel syndrome, and intestinal mucosal mastocytosis is one of its characteristics. In our study, the number of small intestine mast cells in the Salmonella-infected broilers increased significantly, indicating that the broiler intestinal tracts were damaged. Similar findings have been reported in nematode-infected mice. This outcome may be related to promoted mast cell activation, an additional effect of their nonspecific release under stress, infection and inflammatory conditions (Befus et al., 1979; Bienenstock et al., 1979; Gue et al., 1997). Moreover, our present study 
He L, Xu H, Ye F, Yu H, Lu Y, Yin H, Zhao X, Zhu Q, Wang Y
Effects of Glutamine on the Mucosal Structure and Immune Cells in the Intestines of Broiler Chickens Challenged with Salmonella Enteritidis found that GIn supplementation in S. Enteritidisinfected broilers significantly reduced the number of small intestinal mast cells. A previous study showed similar results: GIn was sufficient to reduce the number of gastric mast cells in gastric-damaged mice (Mitra et al., 1977). This finding may be related to the ability of glutamine to reduce the release of lipid mediators and the expression of proinflammatory cytokines, thereby inhibiting mast cell activation (Lechowski et al., 2013).

In addition, our study found that the effect of GIn addition was best at 7 days of age based on data regression analysis. This may be related to the intestinal microorganisms of broilers. Previous studies reported that the diversity of intestinal microbiota of chickens increases with the growth of age, and the ileum microflora can be divided into three stages: 3-5d, 5-12d and $12-17 d$, while the stability of the first stage is the worst (Gong et al., 2013; Hume et al., 2003; Wielen et al.,2002), and the intestinal microorganisms of broilers at 15-22 d gradually tend to mature (Ranjitkar et al., 2016). Moreover, our present study found that there were no significant differences in some indicators of 21-day-old broiler chickens between groups. Kogut's (2009) research shows that determining an animal's ability to respond to a particular pathogenic microorganism depends on the age of the animal. This may be due to the natural and adaptive immunity of the animal's intestine, the structural integrity of the mucosal tissues, and the physiological functions becoming more and more perfect with age.

\section{CONCLUSION}

In our study, $0.5 \%$ and $1.0 \%$ GIn addition to broiler diets effectively alleviated intestinal mucosal damage caused by Salmonella infection and improved its normal defense barrier function, with 1.0\% Gln having the better effect. In addition, the effect of $G$ In addition was best at 7 days of age based on data regression analysis.

\section{ACKNOWLEDGEMENTS}

This research was supported by a project assisted by the National Natural Science Foundation of China (Grant No. 31601971); Natural Science Research Project of Department of Education of Henan Province (Grant No: 17A230001).

The authors express special thanks to Qianqian Wang, Xiuqing Zhou, Yazhe Song, and Jing Zhou for skillful technical assistance with this research.

\section{REFERENCES}

Al-Fataftah A, Abdelqader A. Effects of dietary Bacillus subtilis on heatstressed broilers performance, intestinal morphology and microflora composition. Animal Feed Science and Technology 2014;198:279-285.

Akiba Y, Watanabe C, Mizumori M, Kaunitz JD. Luminal L-glutamate enhances duodenal mucosal defense mechanisms via multiple glutamate receptors in rats. American Journal Physiology Gastrointestinal and Liver Physiology 2009;297(4): G781.

Andrade MA, Stringhini José H, Minafra-Rezende CS, Andrade L, Jayme VS. Histomor-phometrical evaluation of gastrointestinal tract and performance of Ross broilers hatched from eggs inoculated with Salmonella Enteritidis phage type 4. Italian Journal of Animal Science 2013;12(3):e65.

Awad WA, Ghareeb K, Abdel-Raheem S, Böhm J. Effects of dietary inclusion of probiotic and synbiotic on growth performance, organ weights, and intestinal histomorphology of broiler chickens. Poultry Science 2009;88(1):49-56

Barekatain R, Chrystal PV, Howarth GS, McLaughlan CJ, Gilani S, Nattrass GS. Performance, intestinal permeability, and gene expression of selected tight junction proteins in broiler chickens fed reduced protein diets supplemented with arginine, glutamine, and glycine subjected to a leaky gut model. Poultry Science 2019;98(12):6761-6771.

Bartell SM, Batal AB. The effect of supplemental glutamine on growth performance, development of the gastrointestinal tract, and humoral immune response of broilers. Poultry Science 2007; 86(9):1940-1947.

Bischoff SC. Physiological and pathophysiological functions of intestinal mast cells. Seminars in Immunopathology 2009;31(2):185-205.

Bollhalder L, Pfeil AM, Tomonaga Y, Schwenkglenks M. A systematic literature review and meta-analysis of randomized clinical trials of parenteral glutamine supplementation. Clinical Nutrition 2013;32(2):213-223.

Bortoluzzi C, Rochell SJ, Applegate TJ. Threonine, arginine, and glutamine: Influences on intestinal physiology, immunology, and microbiology in broilers. Poultry Science 2017;97(3):937-945.

Chen SY, Xia YY, Zhu GQ, Yan JM, Tan CQ, Deng BC, et al. Glutamine supplementation improves intestinal cell proliferation and stem cell differentiation in weanling mice. Food \& Nutrition Research 2018;62:1439. Available from: https://doi.org/10.29219/fnr.v62.1439.

Chen Y, Tsai YH, Tseng BJ, Tseng SH. Influence of growth hormone and glutamine on intestinal stem cells: a narrative review. Nutrients 2019;11(8):1941

Dinarello CA. Proinflammatory cytokines. Chest 2000;118(2):503-508

Garriga C, Hunter RR, Amat C, Planas JM, Mitchell MA, Moretó M. Heat stress increases apical glucose transport in the chicken jejunum. American Journal of Physiology Regulatory Integrative \& Comparative Physiology 2006;290(1):R195

Galán JE. Interactions of Salmonella with host cells: encounters of the closest kind. Proceedings of the National Academy of Sciences 1998;95(24):14006-14008

Gong J, Yu H, Liu T, Gill JJ, Chambers JR, Wheatcroft R, et al. Effects of zinc bacitracin,bird age and access to range on bacterial microbiota in the ileum and caeca of broiler chickens. Journal of Applied Microbiology 2008; 104(5):1372-1382.

Hartmann RM, Licks F, Schemitt EG, Colares JR, Soares MC, Zabot GP, et al. Protective effect of glutamine on the main and adjacent organs damaged by ischemia-reperfusion in rats. Protoplasma 2017;254:21552168 .

Hohmann EL. Nontyphoidal salmonellosis. Clinical Infectious Diseases 2001;32:263-269. 
Huang ZX, Ye LY, Zheng ZY, Chen XM, Ren RN, Tong GY. Effect of glutamine on small intestinal repair in weanling rats after chronic diarrhea. Zhonghua er ke za zhi. Chinese Journal of Pediatrics 2005;43(5):368372.

Hume ME, Kubena LF, Edrington TS, Donskey CJ, Moore RW, Ricke SC, et al. Poultry digestive microflora biodiversity as indicated by denaturing gradient gel electrophoresis. Poultry Science 2003;82(7):1100-1107.

Jazi V, Foroozandeh AD, Toghyani M, Dastar B, Koochaksaraie RR, Toghyani M. Effects of Pediococcus acidilactici, mannan-oligosaccharide, butyric acid and their combination on growth performance and intestinal health in young broiler chickens challenged with Salmonella Typhimurium. Poultry Science 2018;97(6):2034-2043.

Kew S, Wells SM, Yaqoob P, Wallace FA, Miles EA, Calder PC. Dietary glutamine enhances murine t-lymphocyte responsiveness. Journal of Nutrition 1999; 129(8):1524-1531.

Kim YS, Ho SB. Intestinal goblet cells and mucins in health and disease: recent insights and progress. Current Gastroenterology Reports 2010;12(5):319-330.

Kogut $\mathrm{MH}$. Impact of nutrition on the innate immune response to in-fection in poultry. The Journal Applied Poultry Research 2009;18(1):111-124.

Lechowski S, Feilhauer K, Ludger S. Combined arginine and glutamine decrease release of de novo synthesized leukotrienes and expression of proinflammatory cytokines in activated human intestinal mast cells. European Journal of Nutrition 2013;52(2):505-512.

Martins HA, Sehaber CC, Hermes-Uliana C, Mariani FA, Guarnier FA, Vicentini GE, et al. Supplementation with I-glutamine prevents tumor growth and cancer-induced cachexia as well as restores cell proliferation of intestinal mucosa of walker-256 tumor-bearing rats. Amino Acids 2016;48(12):2773-2784

Mitra R, Pal SP. Inhibition of mast cell population by l-glutamine in aspirininduced ulceration in rat stomach. Indian Journal of Physiology and Pharmacology 1977;21(4):374-378.

Newsholme P. Why is L-glutamine metabolism important to cells of the immune system in health, postinjury, surgery or infection?. The Journal of Nutrition 2001;131(9):5215-2522.

Öhman L, Simrén M. Pathogenesis of ibs: role of inflammation, immunity and neuroimmune interactions. Nature Reviews Gastroenterology \& Hepatology 2010;7(3):163-173.

Paramasivam OR, Trivedi S, Sangith N, Sankaran K. Active sulfite oxidase domain of Salmonella enterica pathogenic protein small intestine invasive factor $\mathrm{E}(\mathrm{SiiE})$ : a potential diagnostic target. Applied microbiology and biotechnology 2019;103:5679-5688.

Schoor DSRDV, Schierbeek $H$, Bet PM, Vermeulen MJ, Lafeber HN, Goudoever JBV, et al. Majority of dietary glutamine is utilized in first pass in preterm infants. Pediatric Research 2010;67(2):194-199.

Shanmugasundaram R, Kogut MH, Arsenault RJ, Swaggerty CL, Cole K, Reddish JM, et al. Effect of Salmonella infection on cecal tonsil regulatory T cell properties in chickens. Poultry Science 2015;94(8):1828-1835.

Shao YX, Lei Z, Yuan JM, Yang Y, Guo YM, Zhang BK. Effect of zinc on growth performance, gut morphometry, and cecal microbial community in broilers challenged with Salmonella entericaserovar typhimurium. Journal of Microbiology 2014;52(12):1002-1011.

Shi Q, Gao G, Xing C, Liu H, Shen P, Pan F, et al. Effects of traditional chinese medicine on numbers of lymphocytes and goblet cells in villus epithelia of layers under heat stress. Agricultural Science and Technology 2015;16(2):311-316.

Souba WW. Glutamine and cancer. Annals of Surgery 1993;218(6):715728.

Sukhotnik I, Agam M, Shamir R, Shehadeh N, Lurie M, Coran AG, et al. Oral glutamine prevents gut mucosal injury and improves mucosal recovery following lipopolysaccharide endotoxemia in a rat. Journal of Surgica Research 2007;143(2):379-384.

Swaid F, Sukhotnik I, Matter I, Berkowitz D, Hadjittofi C, Pollak Y, et al. Dietary glutamine supplementation prevents mucosal injury and modulates intestinal epithelial restitution following acetic acid induced intestinal injury in rats. Nutrition \& Metabolism 2013;53(10). Available from: https://doi.org/10.1186/1743-7075-10-53.

Wang LC, Zhang TT, Wen C, Jiang ZY, Wang T, Zhou YM. Protective effects of zinc-bearing clinoptilolite on broilers challenged with Salmonella Enteritidis. Poultry Science 2012; 91:1838-1845.

Wang J, Chen L, Li P, Li X, Zhou H, Wang F, et al. Gene expression is altered in piglet small intestine by weaning and dietary glutamine supplementation. The Journal of Nutrition 2008;138:1025-1032.

Wang WW, Jia HJ, Zhang HJ, Wang J, Lv HY, Wu SG, et al. Supplemental plant extracts from flos lonicerae in combination with baikal skullcap attenuate intestinal disruption and modulate gut microbiota in laying hens challenged by Salmonella enteritidis. Frontiers in Microbiology 2019;10:1681. Available from: https://doi.org/10.3389/ fmicb.2019.01681.

Wielen PW, Keuzenkamp DA, Lipman LJ, Kanpen F, Biesterveld S. Spatial and temporal variation of the intestinal bacterial community in commercially raised broiler chickens during growth. Microbial Ecology 2002;44(3):286-293.

Wu G, Meier SA, Knabe DA. Dietary glutamine supplementation prevents jejunal atrophy in weaned pigs. Journal of Nutrition 1996;126(10):25782584.

Wu QJ, Jiao C, Liu ZH, Li SW, Zhu DD, Ma WF, et al. Effect of glutamine on the intestinal function and health of broilers challenged with Salmonella pullorum. Indian Journal of Animal Research 2019;53(9):1210-1216.

Wu QJ, Liu N, Wu XH, Wang GY, Lin L. Glutamine alleviates heat stress-induced impairment of intestinal morphology, intestinal inflammatory response, and barrier integrity in broilers. Poultry Science 2018;97(8):2675-2683.

Wu QJ, Liu ZH, Li SW, Jiao C, Wang YQ, Wang Y. Effects of glutamine on digestive function and redox regulation in the intestines of broiler chickens challenged with Salmonella Enteritidis. Brazilian Journal of Poultry Science 2019;21(4):eRBCA-2019-1123.

Wu QJ, Liu ZH, Jiao C, Cheng BY, Zhu DD, Ma Y, Wang YQ, Ma WF, Wang Y. Effects of Glutamine on Growth Performance, Intestinal Morphology and Intestinal Barrier Function of Broilers. Indian Journal of Animal Research 2020; https://doi.org/10.18805/ijar.B-1207.

Wu TY, Zhang HB. Glutamine has a protective role on intestinal tissues via targeting NF-KB pathway in rats with sepsis. European Review for Medical and Pharmacological Sciences 2019;23(3 Suppl):184-191.

Vivinus-Nébot M, Dainese R, Anty R, Saint-Paul MC, Nano JL, Gonthier $\mathrm{N}$, et al. Combination of allergic factors can worsen diarrheic irritable bowel syndrome: role of barrier defects and mast cells. The American Journal of Gastroenterology 2012;107(1):75-81.

Xing S, Zhang B, Lin M, Zhou P, Li J, Zhang L, et al. Effects of alanylglutamine supplementation on the small intestinal mucosa barrier in weaned piglets. Asian-Australasian Journal of Animal Sciences 2017;30(2):236-245.

Xu CL, Sun R, Qiao XJ, Xu CC, Shang XY, Niu WN. Protective effect of glutamine on intestinal injury and bacterial community in rats exposed to hypobaric hypoxia environment. World Journal of Gastroenterol 2014; 16:4662-4674.

Zhen W, Shao Y, Gong X, Wu Y, Geng Y, Wang Z, et al. Effect of dietary Bacillus coagulans supplementation on growth performance and immune responses of broiler chickens challenged by Salmonella enteritidis. Poultry Science 2018;97(8):2654-2666. 